\title{
DATA REPORT: 59. UNSUCCESSFUL SEARCH FOR FISH OTOLITHS, CRETACEOUS AND YOUNGER: LEG 120, SOUTHERN INDIAN OCEAN 1
}

\author{
Patrick G. Quilty²
}

\begin{abstract}
Otoliths were sought in hundreds of samples from Cretaceous to Holocene sections at all sites (747-751) drilled by Ocean Drilling Program Leg 120 on the Kerguelen Plateau. None were recovered. In the younger part of the sequence, the absence is a result of the composition of nototheniid otoliths, which is dominantly aragonite.
\end{abstract}

\section{INTRODUCTION}

No fossil record is known of the predecessors of the fish fauna of the modern Antarctic ecosystem, which is isolated from the other fish faunas of the world by the Antarctic Convergence, an oceanographic boundary usually occurring at approximately $58^{\circ} \mathrm{S}$. Drilling by Ocean Drilling Program (ODP) Legs 119 and 120 (see Table 1 for Leg 120 drill-site locations) provided an unusual opportunity to search for evidence of ancestors, and otoliths were seen to be the ideal remnants of past fish. They also could be sought on a purely opportunistic basis during the processing for other microfossils.

\section{RESULTS}

The search, which was conducted only on Leg 120 material, was unsuccessful, probably because of the fact that modern, and presumably ancient, nototheniid otoliths are dominantly composed of aragonite. Although not pursued in this research, it seems that the otoliths of other Antarctic fish are, and were, probably also aragonitic.

The modern Antarctic ecosystem is characterized by, among other features, its own fish fauna dominated by members of the Suborder Notothenioidei, for which there is no recognized fossil record (Fig. 1). The history of Antarctic fish faunas has been reviewed by Eastman and Grande (1989), who indicated that the origin of the modern notothenioid-dominated fauna is unknown. The modern fauna has been documented by Andriashev (1987) and Gon and Heemstra (in press). The fauna is abundant and diverse. The abundance is obvious as there has developed a major fishery, including one on the northern part of the Kerguelen Plateau, based on nototheniids. Video cameras filming during bit runs on board JOIDES Resolution showed an abundant fish fauna at the drill site.

Otoliths have proved to be very useful in studies of modern Antarctic fish: in identifying species, in estimating the age of individual fish, and in providing an index of size. The modern Antarctic otoliths have been monographed by Hecht (1987) and Williams and McEldowney (in press). This well-known element of the Antarctic fish fauna would, it was hoped, provide the basis for a comparison of modern and fossil faunas. Otoliths have also proved valuable as stratigraphic indexes in their own right and are a common element of some sediment sections elsewhere (Pokorny, 1965).

\footnotetext{
${ }^{1}$ Wise, S. W., Jr., Schlich, R., et al., 1992. Proc. ODP, Sci. Results, 120: College Station, TX (Ocean Drilling Program).

${ }^{2}$ Australian Antarctic Division, Channel Highway, Kingston, Tasmania, Australia, 7050
}

The methodology employed in this study was simple. All Leg 120 core-catcher samples were examined. These are diverse in size but generally are much larger than section samples taken routinely for foraminifer analysis. The total record of these samples is included in the foraminifer results (Quilty, this volume). In addition, much larger samples taken at $145-150$ or $140-150 \mathrm{~cm}$ in each core section were examined when available. These samples were taken for pore-fluid analysis and were subjected to high pressures that compressed them into a circular biscuit about $8 \mathrm{~cm}$ in diameter and $1 \mathrm{~cm}$ thick. These disaggregated successfully during simple processing and yielded well-preserved residues, which were sieved through a $500-\mu \mathrm{m}$ sieve. The coarser fraction was then examined.

All samples were processed by the techniques described in Quilty (this volume), and the $>500-\mu \mathrm{m}$ fraction was examined under a stereo-binocular microscope. The samples that were studied in this way, all barren of fish otoliths, are listed in Table 2.

In addition to the search described above, I also tested the hypothesis that the apparent absence is caused by the aragonitic composition of the otoliths by subjecting several specimens of otoliths of the nototheniid Pagothenia bernacchii (Boulanger) to X-ray diffraction studies at the Geology Department, University of Tasmania. They were shown to be aragonite, as suspected.

Table 1. Locations of Leg 120 sites on the Southern Kerguelen Plateau.

\begin{tabular}{clcc}
\hline Site & Latitude & Longitude & $\begin{array}{c}\text { Water } \\
\text { depth } \\
\text { (m) }\end{array}$ \\
\hline 747 & $54^{\circ} 48.7^{\prime}$ & $76^{\circ} 47.6^{\prime}$ & 1706 \\
748 & $58^{\circ} 26.4^{\prime}$ & $78^{\circ} 59.9^{\prime}$ & 1300 \\
749 & $58^{\circ} 43^{\prime}$ & $76^{\circ} 24.4^{\prime}$ & 1080 \\
750 & $57^{\circ} 35.5^{\prime}$ & $81^{\circ} 14.4^{\prime}$ & 2030 \\
751 & $57^{\circ} 43.6^{\prime}$ & $79^{\circ} 48.9^{\prime}$ & 1634 \\
\hline
\end{tabular}

\section{ACKNOWLEDGMENTS}

I thank R. Williams, Australian Antarctic Division, for his help with literature and his general expertise and for the otoliths used for the XRD analysis; A. McEldowney, Australian Antarctic Division, for providing the illustration used; and D. H. Green, Geology Department, University of Tasmania, for having the analyses conducted at very short notice. 


\section{REFERENCES}

Andriashev, A. P., 1987. A general review of the Antarctic bottom fish fauna. Proc. Fifth Congr. Eur. Ichthyologists, Stockholm, $1985,357-372$.

Eastman, J. T., and Grande, L., 1989. Evolution of the Antarctic fish fauna with emphasis on the Recent notothenioids. In Crame, J. A. (Ed.), Origins and Evolution of the Antarctic Biota. Spec. Publ., Geol. Soc., 47:241-252.

Gon, O., and Heemstra, P. C., in press. Fishes of the Southern Ocean: Capetown (Southern Book Publishers).

Hecht, T., 1987. A guide to the otoliths of Southern Ocean fishes. $S$. Afr. J. Antarct. Res., 17(1):2-87.

Pokorny, V., 1965. Principles of Zoological Micropalaeontology (Vol. 2): Oxford (Pergamon Press).

Williams, R., and McEldowney, A., in press. An atlas of fish otoliths from waters of the Australian Antarctic Territory and Heard and Macquarie Islands. ANARE Sci. Rep.

Date of initial receipt: 16 January 1990

Date of acceptance: 27 September 1990

Ms 120B-194
Table 2. Samples (other than core catcher) processed in the search for otoliths.

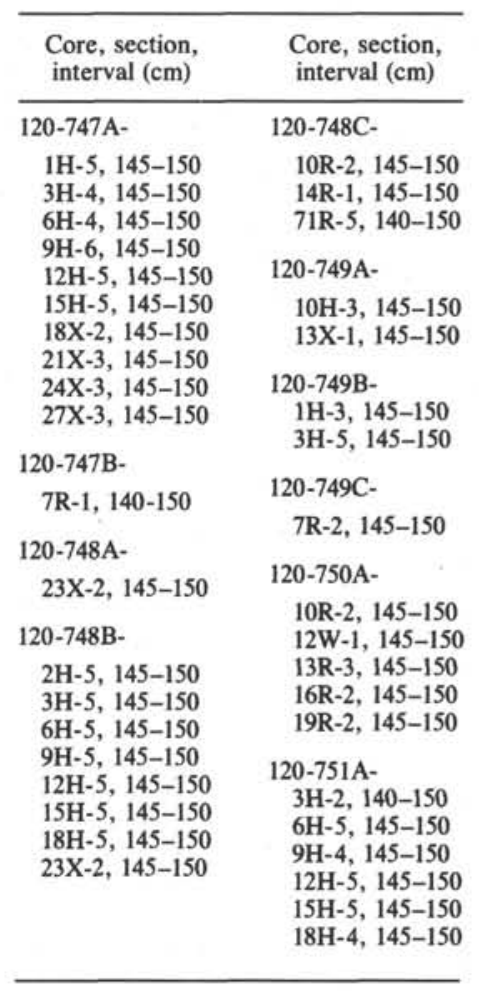

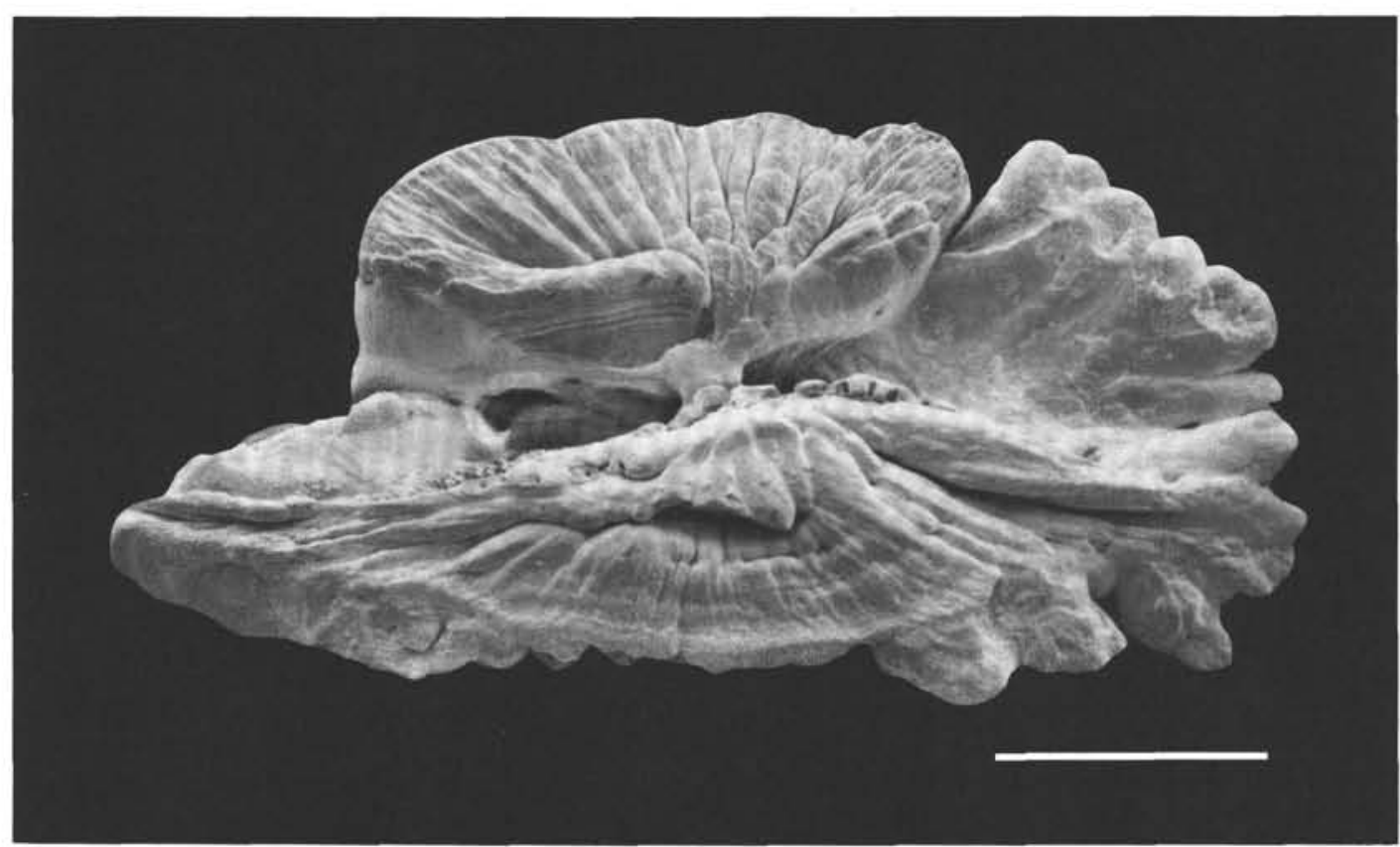

Figure 1. Modern otolith of the nototheniid Notothenia coriiceps Richardson, which occurs in the region drilled during Leg 120 (courtesy of R. Williams and A. McEldowney). Scale bar represents $1 \mathrm{~mm}$. 